\title{
OUTPATIENT ANALYTIC ASSESSMENT OF ANOREXIA NERVOSA - THE IMPORTANCE OF VENOUS BLOOD GASES
}

\section{Avaliação laboratorial em ambulatório na anorexia nervosa: a importância da gasometria venosa}

\author{
Sofia Alexandra Pereira Pires ${ }^{a *}$ (D), Joana Costa Soares ${ }^{b}$ (D), \\ Alexandra Maria Branco da Luz $^{b}$ (1), Pascoal Moleiro ${ }^{b}$
}

\section{ABSTRACT}

Objective: To evaluate serum biochemical parameters' evolution, especially venous blood gas (VBG), in anorexia nervosa (AN), correlating with clinical parameters.

Methods: Retrospective study including out-patient AN adolescents, between January 2014 and May 2017. Three evaluations were compared: $t 1$ ) first consultation; t2) consultation with the lowest body mass index (BMI) z-score and $t 3$ ) with the highest BMI z-score.

Results: A total of 24 adolescents (87.5\% females) were included, mean age of presentation of $14.9 \pm 1.7$ years, onset of symptoms $6.4 \pm 3.2$ months before the first visit. In $t 1$, BMI $z$-score of $-1.91 \pm 1.11 \mathrm{~kg} / \mathrm{m}^{2}$ and ideal weight $\%$ of $84.3 \pm 9.2$. Amenorrhea was present in $88 \%$. In $t 2$ the analytical alterations were: altered VBG in $100 \%$, altered ferritin ( $72 \%$ elevated), altered thyroid function (53\% with thyroxine decrease), dyslipidemia (31\% elevation of high density lipoprotein, 25\% hypercholesterolemia), elevation of urea (25\%), elevation of alanine aminotransferase (14\%), hypoglycemia (14\%), anemia (9\%). Respiratory acidosis was present in $91 \%$ in $t 1,100 \%$ in $t 2$ and $94 \%$ in $t 3$. There was a significant decrease between $t 2$ and $t 3$ in mean $\mathrm{pCO}^{2}(57.2$ versus $53.6 \mathrm{mmHg} ; \mathrm{p}=0.009)$ and mean $\mathrm{HCO}_{3}$ (30.0 versus $28.8 \mathrm{mEq} / \mathrm{L} ; \mathrm{p}=0.023$ ).

Conclusions: Respiratory acidosis and increased ferritin were common in this group. Respiratory acidosis was the most frequent abnormality with significant pCO2 and $\mathrm{HCO}_{3}$ variation in the recovery phase. VBG should be considered in AN evaluation, once it seems to be important in assessing the severity of the disease and its subsequent follow-up.

Keywords: Anorexia nervosa; Adolescent; Malnutrition; Blood gas analysis.

\section{RESUMO}

Objetivo: Avaliar a evolução laboratorial, particularmente da gasometria venosa, na anorexia nervosa (AN), correlacionando os achados com parâmetros clínicos.

Métodos: Estudo retrospetivo com adolescentes com AN seguidos em ambulatório, entre janeiro de 2014 e maio de 2017. Foram comparadas três avaliações: (t1) primeira consulta; (t2) consulta com escore $Z$ de índice de massa corpórea (IMC) mais baixo; e (t3) consulta com escore $Z$ de IMC mais elevado.

Resultados: Incluídos 24 adolescentes, 87,5\% do sexo feminino, idade média de apresentação de 14,9 $\pm 1,7$ anos, início dos sintomas $6,4 \pm 3,2$ meses antes da primeira consulta. Em t1, escore Z de IMC de $-1,91 \pm 1,11 \mathrm{~kg} / \mathrm{m}^{2}$ e $\%$ de peso ideal de $84,3 \pm 9,2$. Tinham amenorreia 88\%. Em t2 as alterações laboratoriais encontradas foram: gasometria venosa alterada em $100 \%$, ferritina alterada (72\% elevada), função tiroideia alterada (53\% com diminuição da tiroxina), dislipidemia (31\% com elevação de lipoproteína de alta densidade, 25\% com hipercolesterolemia), elevação da ureia (25\%), elevação da alanina aminotransferase (14\%), hipoglicemia (14\%) e anemia (9\%). Aacidose respiratória esteve presente em 91\% em t1, 100\% em t2 e $94 \%$ em $t 3$. Verificou-se diminuição significativa entre t2 e $t 3$ da pressão parcial de $\mathrm{CO}_{2}\left(\mathrm{pCO}_{2}\right)$ média $(57,2$ versus $53,6 \mathrm{mmHg} ; \mathrm{p}=0,009)$ e $\mathrm{HCO}_{3}$ médio $(30,0$ versus $28,8 \mathrm{mEq} / \mathrm{L} ; \mathrm{P}=0,023)$.

Conclusões: $A$ acidose respiratória e o aumento da ferritina foram comuns nesse grupo. Acidose respiratória foi a alteração mais frequente, com variação significativa de $\mathrm{pCO}_{2}$ e $\mathrm{HCO}_{3}$ na fase de recuperação. A gasometria venosa deve ser considerada na avaliação laboratorial na AN, pois parece ser importante na avaliação da gravidade e monitorização da doença.

Palavras-chave:Anorexia nervosa;Adolescente; Desnutrição; Gasometria. 


\section{INTRODUCTION}

Anorexia nervosa (AN) is a multifactorial eating disorder with 0.5 to $2 \%$ prevalence in the general population. It is more frequent among females and its incidence peak of disease onset is between 13 and 18 years. ${ }^{1-5} \mathrm{AN}$-associated mortality is 5 to $6 \%$, the highest rate for women by a psychiatric illness. ${ }^{3}$

Since 2013, its diagnosis has been based on the criteria of the Diagnostic and Statistical Manual of Mental Disorder V (DSM-5), ${ }^{6}$ divided into restrictive and compulsive/purgative subtypes. This classification allowed to decrease the prevalence of diagnosis of eating disorder without further specification, to the detriment of the increase in AN cases, allowing for greater therapeutic and prognostic accuracy. ${ }^{7}$

The combination of malnutrition implicated in AN and potentially associated behaviors, such as vomiting and use of laxatives, may impact various organs and systems, and be associated with various laboratory abnormalities. ${ }^{8-10}$ The most commonly described laboratory abnormalities are: electrolyte disorders such as hypophosphatemia and hypokalemia due to vomiting and the use of laxative/diuretic substances. ${ }^{2,8}$ Endocrine dysfunction is relatively frequent and includes hypothyroidism, hypercortisolism, and hypothalamus-pituitary axis disorders manifested by hypogonadotropic hypogonadism. and anovulation. ${ }^{9}$ The most common alteration is the euthyroid syndrome (low levels of thyroxine with normal thyrotropin), reversible with reestablishment of feeding. ${ }^{1}$ Patients may also have impaired kidney function associated with acute renal failure due to vomiting or severe fluid restriction. ${ }^{2}$ Other changes are hematological disorders such as anemia and leukopenia, with rare cases of thrombocytopenia. It is important to assess iron and vitamin B12 levels in anemic patients because supplementation is recommended in cases of deficiency. ${ }^{2}$ Elevation of transaminases is common, usually asymptomatic and self-limiting, but in rare cases may be associated with liver injury. ${ }^{8}$ Mild hypoglycaemia is a common finding in AN and is usually well tolerated. ${ }^{8}$ Serum albumin is normal in most patients, even in severe cases. ${ }^{8}$ Several studies have shown elevated levels of total cholesterol (TC), high density lipoprotein (LDL) and low density lipoprotein (HDL). The cause is not fully understood, but there are studies linking this finding to reduced catabolism and decreased thyroxine (T3) ${ }^{8}$ Changes in acid-base balance, such as metabolic alkalosis in patients with purgative or behavioral disorders, are also described in patients who make use of diuretics. ${ }^{1,8,11}$ Studies in hospitalized patients have shown that respiratory acidosis is also a common finding in AN. ${ }^{11,12}$ However, blood gas analysis is not part of the routine laboratory evaluation of most centers, particularly in outpatient follow-up.

Several laboratory parameters related to nutritional status are routinely evaluated after the diagnosis of AN..$^{1,13}$
However, even in severe cases, laboratory evaluation may not change. ${ }^{14}$ The explanation for this fact seems to lie in the compensation. of the effects of malnutrition, which preserves most physiological functions through adaptive mechanisms, ${ }^{14,15}$ although clinical parameters of malnutrition are present.

Most longitudinal studies on laboratory abnormalities in AN patients are performed with hospitalized patients, ${ }^{11,14-16}$ in whom a more pronounced metabolic imbalance can be predicted. There are few studies analyzing the evolution of laboratory parameters in patients with AN followed up in outpatient clinic $^{10,17}$ that allow to infer their role in risk stratification and clinical monitoring of these patients.

Establishing a laboratory parameter that correlates with clinical outcome/severity is important for therapeutic monitoring and also for patient awareness of the need for treatment. Thus, the objective of this study was to evaluate the evolution of laboratory parameters, particularly venous blood gas analysis in AN patients followed up at an outpatient clinic, and relate them with clinical parameters.

\section{METHOD}

An analytical cross-sectional study was conducted with retrospective data collection from a convenience sample. Data were analyzed from clinical records of adolescents with AN diagnosed based on DSM-5 criteria and followed up at the adolescent medicine consultation of a level II hospital, between January 2014 and May 2017.

Three points were considered for the evaluation of anthropometric and laboratory parameters: ( $\mathrm{t} 1$ ) first consultation; ( $\mathrm{t} 2$ ) consultation with the lowest body mass index (BMI) Z-score; and (t3) consultation with the highest BMI Z-score. In some cases, the consultation with the lowest BMI Z-score (t2) corresponded to the first consultation $(\mathrm{t} 1)$.

At each of these assessment points the following anthropometric data were analyzed: weight, height, BMI, BMI percentile, BMI Z-score and \% of ideal weight. The BMI percentile and Z-score were calculated using the BMI calculator for children and adolescents, available at https://zscore.research. chop.edu/index.php. To determine the ideal weight of adolescents, the weight corresponding to BMI at the 50th percentile (P50) for age and sex was calculated using the formula: target weight $(\mathrm{kg})=$ BMI at P50 $\left(\mathrm{kg} / \mathrm{m}^{2}\right) \times$ height (meters). ${ }^{2}$ The $\%$ of ideal weight was calculated using the formula: actual weight $\times 100 /$ target weight.

At the three assessment points, blood pressure (BP) and heart rate $(\mathrm{HR})$ were also evaluated. Bradycardia was considered when $\mathrm{HR}<60 \mathrm{bpm}$ and hypotension when systolic $\mathrm{BP}<90 \mathrm{mmHg}$. 
The laboratory parameters analyzed were: hemoglobin $(\mathrm{g} / \mathrm{dL})$, sodium $(\mathrm{mmol} / \mathrm{L})$, potassium $(\mathrm{mmol} / \mathrm{L})$, magnesium $(\mathrm{mmol} / \mathrm{L})$, phosphate $(\mathrm{mmol} / \mathrm{L})$, calcium, total cholesterol, triglycerides, LDL, HDL, creatinine kinase (CK) $(\mathrm{U} / \mathrm{L})$, albumin, creatinine $(\mathrm{mg} / \mathrm{dL})$, urea $(\mathrm{mmol} / \mathrm{L})$, thyrotropin $(\mathrm{TSH})$, free $\mathrm{T} 4$, total protein $(\mathrm{g} / \mathrm{dL})$, glucose $(\mathrm{mg} /$ $\mathrm{dL}$ ), aspartate aminotransferase (AST) (U/L), alanine aminotransferase (ALT) (U/L), lactic dehydrogenase (LDH) $(\mathrm{U} / \mathrm{L})$, ferritin $(\mathrm{ng} / \mathrm{mL})$ and $\mathrm{pH}, \mathrm{CO}_{2}$ partial pressure $\left(\mathrm{pCO}_{2}\right.$ ) and $\mathrm{HCO}_{3}$ (venous blood gas analysis). Like other authors, ${ }^{11}$ in this study we used arterial blood gas reference values to analyze venous blood gas results. Some authors ${ }^{18,19}$ have shown a high degree of agreement between arterial and venous blood gas values.

Considering the ease of obtaining a venous blood sample, there is no theoretical or practical reason to justify the need to use arterial blood gas in AN patients. As reference values for the remaining analyses, internationally accepted values were considered at the pediatric age, ${ }^{20}$ as well as the reference values for pediatric age for dyslipidemia, from the Portugal General Directorate for Health. ${ }^{21}$ Data were also analyzed as age at first visit, gender, duration of disease, presence of amenorrhea and severity of AN (mild: BMI $\geq 17 \mathrm{~kg} / \mathrm{m}^{2}$; $\bmod -$ erate: BMI 16 to $16.9 \mathrm{~kg} / \mathrm{m}^{2}$; severe: BMI 15 to $15.9 \mathrm{~kg} / \mathrm{m}^{2}$; extreme: $\mathrm{BMI}<15 \mathrm{~kg} / \mathrm{m}^{2}$ ).

For comparative analysis, the Student's t-test for paired samples was used to compare means and the McNemar's test for categorical variables. To investigate the correlation between quantitative variables, we used the Pearson's (r) or Spearman's (rho) coefficient, according to normality. The absolute value of correlation indicates the intensity of the association, considering $\mathrm{r} / \mathrm{rho} \leq 0.19$ : very low correlation; $0.2 \leq \mathrm{r} / \mathrm{rho} \leq 0.39$ : low correlation; $0.4 \leq \mathrm{r} / \mathrm{rho} \leq 0.69$ : moderate correlation; $0.7 \leq \mathrm{r} / \mathrm{rho} \leq 0.89$ : strong correlation; $0.9 \leq \mathrm{r} / \mathrm{rho} \leq 1$ : very strong correlation. ${ }^{22}$ Statistical treatment was performed using the Statistical Package for Social Sciences (SPSS) $22^{\circ}$ (IBM Corp. Armonk, NY, USA). Statistical significance was set for $\mathrm{p}<0.05$.

The survey and consultation of clinical records were made respecting the confidentiality of adolescents' data; and data collection complied with the principles of the Declaration of Helsinki. The study was authorized by the service director, as well as by the Hospital Research Ethics Committee.

\section{RESULTS}

A sample of 24 adolescents was obtained, 21 participants being females (87.5\%). Three patients were seen at only one consultation during the study and, therefore, have only the laboratory evaluation for $\mathrm{t} 1$.
At their first appointment, the patients had a mean age of $14.9 \pm 1.7$ years and onset of symptoms $6.4 \pm 3.2$ months earlier.

The ideal weight percentage was $84.3 \pm 9.2 \%$; the BMI percentile was $13.2 \pm 16.4$; and the BMI Z-score was $-1.91 \pm 1.11$. Regarding AN severity, $66.7 \%$ of the sample had mild to moderate AN, with no statistically significant differences regarding gender $(\mathrm{p}=0.526)$. Note that 4 patients $(16.7 \%)$ had a BMI $<15 \mathrm{~kg} / \mathrm{m}^{2}$, which corresponds to a degree of extreme severity.

Of female adolescents with menarche $(n=17), 88 \%$ had secondary amenorrhea.

As for the vital parameters evaluated, $62.5 \%$ presented bradycardia and $12.5 \%$ had hypotension. Patients with severe and extreme AN presented bradycardia and hypotension more often than patients with mild to moderate AN $(87.5$ versus $50 \%$; $\mathrm{p}=0.074$; and 25 versus $6.3 \%$; $\mathrm{p}=0.19$, respectively). Table 1 shows the characteristics of the sample upon first consultation.

Between $\mathrm{t} 2$ and $\mathrm{t} 3$, the increase in BMI Z-score was accompanied by a significant increase in HR $(60.1 \pm 13.4$ versus $70.8 \pm 14.6 ; \mathrm{p}=0.022)$ and $\mathrm{BP}(97.3 \pm 10.1$ versus $102.2 \pm 11.2$; $\mathrm{p}=0.031$ ), as shown in Table 2 .

Table 1 Sample characterization at the first appointment $(n=24)$.

\begin{tabular}{l|c}
\hline Parameters & First appointment \\
\hline Age (years) & $14.9 \pm 1.7$ (variation 11-18) \\
\hline Female/male (n) & $21 / 3$ \\
\hline $\begin{array}{l}\text { Time since symptoms onset } \\
\text { (months) }\end{array}$ & $6.4 \pm 3.2$ (variation 2-12) \\
\hline Ideal weight $\%$ & $84.3 \pm 9.2$ \\
\hline BMl Z-score & $-1.91 \pm 1.11$ \\
\hline Severity & \\
\hline Mild & 9 \\
\hline Moderate & 7 \\
\hline Severe & 4 \\
\hline Extreme & 4 \\
\hline $\begin{array}{l}\text { Amenorrhea } \\
\text { (with menarche } \mathrm{n}=17)\end{array}$ & $15(88 \%)$ \\
\hline HR (bpm) & \\
\hline Mean \pm SD & $58.3 \pm 13.7$ \\
\hline$\%$ bradycardia & 62.5 \\
\hline Systolic BP (mmHg) & \\
\hline Mean $\pm S D$ & $99.3 \pm 9.0$ \\
\hline$\%$ hypotension & 12.5 \\
\hline
\end{tabular}

BMI: body mass index; HR: heart rate; SD: standard deviation; BP: blood

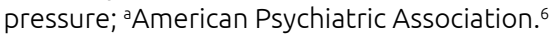


The exams requested in each laboratory evaluation ( $\mathrm{t} 1, \mathrm{t} 2$ and $\mathrm{t} 3$ ) varied, with blood count and glucose requested in all evaluations. In addition to these, the most frequent tests were: urea, creatinine, TSH, free T4, complete ionogram, lipid profile, transaminases and venous blood gases, requested in more than $75 \%$ of cases. Their analysis is presented in Table 3 .

Considering the laboratory evaluation performed with the lowest BMI ( $\mathrm{t} 2)$, most laboratory parameters were normal. Changes found were: venous blood gas analysis $(100 \%$ $\mathrm{pCO}_{2}$ elevation, $75 \% \mathrm{HCO}_{3}$ elevation, $70 \%$ acidosis), ferritin (72\% elevated, $14 \%$ decreased), thyroid function $(53 \%$ decreased thyroxine, $6 \%$ decreased thyrotropin), dyslipidemia (31\% with elevated LDL, $25 \%$ with hypercholesterolemia), elevated urea (25\%), elevated ALT (14\%), hypoglycemia (14\%) and anemia $(9 \%)$.

Considering the mean laboratory parameters, venous blood gas and ferritin (in females) were the only altered parameters (Table 3). Ferritin was high in $\mathrm{t} 1$ and $\mathrm{t} 2(163.2$ and $191.6 \mathrm{ng} / \mathrm{mL}$, respectively), considering the reference values for females. Its value decreased between $\mathrm{t} 2$ and $\mathrm{t} 3$, without statistical significance ( $\mathrm{p}=0.196)$. No significant correlation was found between ferritin values and BMI Z-score. Although the lipid profile values were within the limits established as reference, there was a significant decrease, between $\mathrm{t} 2$ and $\mathrm{t} 3$, of the mean total cholesterol (167.4 versus $148.5 \mathrm{mg} / \mathrm{dL} ; \mathrm{p}=0.026)$ and LDL (98.4 versus $83.8 \mathrm{mg} / \mathrm{dL} ; \mathrm{p}=0.025)$.

There is a positive correlation between BMI Z-score variation and mean glucose variation between $\mathrm{t} 2$ and $\mathrm{t} 3$ (rho=0.464; $\mathrm{p}=0.034)$.

Venous blood gas results are shown in Table 4. Respiratory acidosis (compensated or not) was present in 20 patients at $\mathrm{t} 1$ (91\%), 20 patients at $\mathrm{t} 2(100 \%)$ and 16 patients at $\mathrm{t} 3(94 \%)$. The blood gas parameters at first visit did not correlate with the duration of disease or with the $\mathrm{Z}$ score at $\mathrm{t} 1$. There was a decrease in the number of unbalanced acidoses from $t 2$ to t3 (without statistical significance; $\mathrm{p}=0.453$ ). There was also a significant decrease between $\mathrm{t} 2$ and $\mathrm{t} 3$ of mean $\mathrm{pCO}_{2}(57.2$ versus $53.6 \mathrm{mmHg} ; \mathrm{p}=0.009)$ and mean $\mathrm{HCO}_{3}(30.0$ versus $28.8 \mathrm{mEq} / \mathrm{L} ; \mathrm{p}=0.023)$.

\section{DISCUSSION}

In this study, most of the laboratory parameters usually requested for patients with anorexia nervosa presented means values within the reference range, except for venous blood gas and ferritin parameters. At the greatest clinical severity ( $\mathrm{t} 2$ - lowest BMI and most often presence of bradycardia and hypotension), the most frequent laboratory abnormalities were found in venous blood gas analysis. In order of frequency, ferritin alterations $(72 \%$ with elevation), altered thyroid function (53\% with decreased thyroxine), dyslipidemia (31\% with elevated LDL, 25\% with hypercholesterolemia), elevated urea (25\%), increased ALT (14\%), hypoglycemia (14\%) and anemia (9\%) were also found.

There is great variability in the results of studies evaluating laboratory changes in AN, due to the heterogeneity of the methodology used (laboratory parameters analyzed, inpatients/ outpatients, comparison with reference values/control groups). Nova et al. ${ }^{14,15}$ analyzed hospitalized (and probably more decompensated) patients compared to a control group and described frequent laboratory abnormalities, especially in blood count, blood glucose, total proteins, transaminases, LDH, CK and ferritin. In these patients recruited during hospitalization, the presence of dyslipidemia was less frequent than in our study (18\% hypercholesterolemia and $16 \%$ elevation of LDL). ${ }^{23}$ Also compared to the findings of this study, in other outpatient studies $^{10,17}$ anemia was more frequent $(38.6 \%)$, as were hydroelectrolytic changes (hyponatremia in $19.7 \%$ and hypokalemia in 19.7\%), but with similar ALT elevation values (12.2\%).

These results show that laboratory alterations may be uncommon, even in severe patients. Laboratory "normality"

Table 2 Characterization of vital parameters and association with body mass index.

\begin{tabular}{|c|c|c|c|c|}
\hline Parameters & $\mathbf{t 1}$ & t2 & t3 & p-value ${ }^{a}$ \\
\hline BMI score (MeanıSD) & $-1.65 \pm 1.13$ & $-2.41 \pm 1.31$ & $-0.85 \pm 0.90$ & $<0.001$ \\
\hline \multicolumn{5}{|l|}{ HR (bpm) } \\
\hline Mean $\pm S D$ & $58.3 \pm 13.7$ & $60.1 \pm 13.4$ & $70.8 \pm 14.6$ & \multirow{2}{*}{0.022} \\
\hline \% bradycardia & 62.5 & 60 & 23.8 & \\
\hline \multicolumn{5}{|l|}{ Systolic BP (mmHg) } \\
\hline Mean $\pm S D$ & $99.3 \pm 9.0$ & $97.3 \pm 10.1$ & $102.2 \pm 11.2$ & \multirow{2}{*}{0.031} \\
\hline$\%$ hypotension & 12.5 & 20 & 10 & \\
\hline
\end{tabular}

BMI: body mass index; SD: standard deviation; HR: heart rate; BP: blood pressure; aStudent's t-test for paired samples (between means of $t 2$ and $t 3)$. 
Table 3 Laboratory parameters of patients with anorexia nervosa at the three moments of analysis.

\begin{tabular}{|c|c|c|c|c|c|}
\hline & Reference values & $\begin{array}{c}\mathrm{t} 1(\mathrm{n}=24) \\
(\mathrm{mean} \pm \mathrm{SD}) \\
\text { (normal value in \%) }\end{array}$ & $\begin{array}{c}\text { t2 }(\mathrm{n}=21) \\
\text { (mean } \pm \mathrm{SD}) \\
\text { (normal value in \%) }\end{array}$ & $\begin{array}{c}\text { t3 }(n=21) \\
\text { (meantsD) } \\
\text { (normal value in \%) }\end{array}$ & p-value ${ }^{a}$ \\
\hline $\mathrm{Hb}(\mathrm{g} / \mathrm{dL})$ & $\begin{array}{c}M(12.5-16.1) \\
F(12-15)\end{array}$ & $\begin{array}{c}13.6 \pm 1.5 \\
88\end{array}$ & $\begin{array}{c}13.4 \pm 1.6 \\
86\end{array}$ & $\begin{array}{c}13.1 \pm 1.2 \\
81\end{array}$ & 0.395 \\
\hline Glucose (mg) & $60-100$ & $\begin{array}{c}75.5 \pm 12.1 \\
83\end{array}$ & $\begin{array}{c}76.2 \pm 15.7 \\
81\end{array}$ & $\begin{array}{l}79.2 \pm 10.9 \\
86\end{array}$ & 0.438 \\
\hline Total proteins (g/dL) & $66-82$ & $\begin{array}{l}74.3 \pm 4.5 \\
95\end{array}$ & $\begin{array}{c}72.9 \pm 5.3 \\
94\end{array}$ & $\begin{array}{c}72.8 \pm 3.6 \\
93\end{array}$ & 0.735 \\
\hline AST (U/L) & $\begin{array}{l}10-15 Y(10-40) \\
16-19 Y(15-45)\end{array}$ & $\begin{array}{c}25.2 \pm 7.4 \\
96\end{array}$ & $\begin{array}{c}24.1 \pm 5.6 \\
100\end{array}$ & $\begin{array}{c}25.9 \pm 6.7 \\
100\end{array}$ & 0.137 \\
\hline $\mathrm{ALT}(\mathrm{U} / \mathrm{L})$ & $5-45$ & $\begin{array}{c}26.3 \pm 11.7 \\
92\end{array}$ & $\begin{array}{c}27.5 \pm 12.9 \\
86\end{array}$ & $\begin{array}{c}32.7 \pm 21.7 \\
85\end{array}$ & 0.366 \\
\hline $\mathrm{LDH}(\mathrm{U} / \mathrm{L})$ & $120-330$ & $\begin{array}{c}208.1 \pm 47.7 \\
100\end{array}$ & $\begin{array}{c}183.7 \pm 27.0 \\
100\end{array}$ & $\begin{array}{l}185.5 \pm 20.8 \\
100\end{array}$ & 0.973 \\
\hline CK (U/L) & $5-130$ & $\begin{array}{c}97.8 \pm 45.8 \\
75\end{array}$ & $\begin{array}{c}68.7 \pm 20.9 \\
100 \%\end{array}$ & $\begin{array}{l}72.4 \pm 26.8 \\
100\end{array}$ & 0.715 \\
\hline Urea (mmol/L) & $2.5-6.4$ & $\begin{array}{c}6.2 \pm 3.9 \\
75\end{array}$ & $\begin{array}{c}5.3 \pm 1.4 \\
75\end{array}$ & $\begin{array}{c}6.4 \pm 4.2 \\
76\end{array}$ & 0.224 \\
\hline Creatinine (mg/dL) & $\begin{array}{c}10-14 Y(0.31-0.88) \\
15-19 Y(0.5-1.06)\end{array}$ & $\begin{array}{c}0.8 \pm 0.2 \\
96\end{array}$ & $\begin{array}{c}0.7 \pm 0.1 \\
100\end{array}$ & $\begin{array}{c}0.7 \pm 0.1 \\
95\end{array}$ & 0.051 \\
\hline $\mathrm{HDL}(\mathrm{mg} / \mathrm{dL})$ & $>35$ & $\begin{array}{c}58.4 \pm 11.3 \\
100\end{array}$ & $\begin{array}{c}57.0 \pm 9.23 \\
100\end{array}$ & $\begin{array}{c}61.3 \pm 14.6 \\
100\end{array}$ & 0.332 \\
\hline LDL (mg/dL) & $<130$ & $\begin{array}{c}98.6 \pm 39.4 \\
80\end{array}$ & $\begin{array}{c}99.8 \pm 41.7 \\
69\end{array}$ & $\begin{array}{l}84.7 \pm 28.2 \\
94\end{array}$ & 0.025 \\
\hline $\mathrm{TC}(\mathrm{mg} / \mathrm{dL})$ & $<200$ & $\begin{array}{c}165.5 \pm 53.2 \\
70\end{array}$ & $\begin{array}{c}165.0 \pm 45.4 \\
75\end{array}$ & $\begin{array}{c}151.2 \pm 47.0 \\
89\end{array}$ & 0.026 \\
\hline TG (mg/dL) & $<150$ & $\begin{array}{l}72.3 \pm 22.9 \\
100\end{array}$ & $\begin{array}{c}68.6 \pm 24.6 \\
100\end{array}$ & $\begin{array}{c}71.9 \pm 0.4 \\
94 \%\end{array}$ & 0.999 \\
\hline TSH (uUI/mL) & $0.5-4.5$ & $\begin{array}{c}1.8 \pm 0.8 \\
95\end{array}$ & $\begin{array}{l}1.55 \pm 0.8 \\
94\end{array}$ & $\begin{array}{c}1.7 \pm 0.7 \\
100\end{array}$ & 0.173 \\
\hline T4L (pmol/L) & $9-25.7$ & $\begin{array}{c}9.9 \pm 1.3 \\
84\end{array}$ & $\begin{array}{c}9.3 \pm 1.6 \\
47\end{array}$ & $\begin{array}{c}8.9 \pm 2.3 \\
53\end{array}$ & 0.748 \\
\hline $\mathrm{K}(\mathrm{mmol} / \mathrm{L})$ & $3.3-4.6$ & $\begin{array}{c}4.3 \pm 0.3 \\
96\end{array}$ & $\begin{array}{c}4.0 \pm 0.3 \\
100\end{array}$ & $\begin{array}{c}4.1 \pm 0.3 \\
90\end{array}$ & 0.257 \\
\hline $\mathrm{Na}(\mathrm{mmol} / \mathrm{L})$ & $134-145$ & $\begin{array}{l}139.3 \pm 1.6 \\
100\end{array}$ & $\begin{array}{l}140.0 \pm 1.6 \\
100\end{array}$ & $\begin{array}{l}139.7 \pm 2.7 \\
100\end{array}$ & 0.419 \\
\hline $\mathrm{Ca}(\mathrm{mmol} / \mathrm{L})$ & $2.2-2.7$ & $\begin{array}{l}2.4 \pm 0.4 \\
86\end{array}$ & $\begin{array}{c}2.3 \pm 0.5 \\
79\end{array}$ & $\begin{array}{c}2.2 \pm 0.4 \\
89 \%\end{array}$ & 0.924 \\
\hline $\mathrm{Mg}(\mathrm{mmol} / \mathrm{L})$ & $0.6-0.95$ & $\begin{array}{c}0.9 \pm 0.1 \\
77 \%\end{array}$ & $\begin{array}{c}0.9 \pm 0.1 \\
88\end{array}$ & $\begin{array}{c}0.8 \pm 0.1 \\
94\end{array}$ & 0.401 \\
\hline Phosphate (mmol/L) & $\begin{array}{c}\text { 12-15Y: } 0.95-1.75 \\
\text { 16-19Y: } 0.9-1.5\end{array}$ & $\begin{array}{c}1.3 \pm 0.2 \\
100\end{array}$ & $\begin{array}{c}1.3 \pm 0.2 \\
100\end{array}$ & $\begin{array}{c}1.3 \pm 0.2 \\
100\end{array}$ & 0.975 \\
\hline Ferritin (ng/mL) & $\begin{array}{l}\text { M: } 10-300 \\
\text { F: } 10-70\end{array}$ & $\begin{array}{c}160.8 \pm 159.9 \\
(F: 163.2 \pm 169.4)^{b} \\
10\end{array}$ & $\begin{array}{c}191.7 \pm 182.7 \\
(F: 191.6 \pm 182.7)^{b} \\
14\end{array}$ & $\begin{array}{c}70.0 \pm 39.6 \\
(F: 74.2 \pm 40.9)^{b} \\
37\end{array}$ & $\begin{array}{c}0.196 \\
(F 0.196)\end{array}$ \\
\hline Venous $\mathrm{pH}$ & $7.35-7.45$ & $\begin{array}{c}7.34 \pm 0.03^{b} \\
59\end{array}$ & $\begin{array}{c}7.33 \pm 0.02^{\mathrm{b}} \\
30\end{array}$ & $\begin{array}{c}7.34 \pm 0.02^{\mathrm{b}} \\
47\end{array}$ & 0.213 \\
\hline $\mathrm{pCO}_{2}(\mathrm{mmHg})$ & $<45$ & $\begin{array}{c}53.8 \pm 6.5^{b} \\
5\end{array}$ & $\begin{array}{c}56.6 \pm 5.1^{\mathrm{b}} \\
0\end{array}$ & $\begin{array}{c}53.5 \pm 5.2^{b} \\
6\end{array}$ & 0.009 \\
\hline $\mathrm{HCO}_{3}(\mathrm{mmHg})$ & $\begin{array}{l}22-29 \text { (venous) } \\
21-28 \text { (arterial) }\end{array}$ & $\begin{array}{c}28.9 \pm 2.0 \\
36\end{array}$ & $\begin{array}{c}29.9 \pm 1.6 \\
25\end{array}$ & $\begin{array}{c}28.7 \pm 2.5 \\
47\end{array}$ & 0.023 \\
\hline
\end{tabular}

SD: standard deviation; $\mathrm{Hb}$ : hemoglobin; AST: aspartate aminotransferase; Y: Years ago; ALT: alanine aminotransferase; LDH: lactate dehydrogenase; CK: creatinine kinase; HDL: high density lipoprotein; LDL: low density lipoprotein; TC: total cholesterol; TG: triglycerides; TSH: thyrotropin; T4L: free thyroxine; $\mathrm{K}$ : potassium; Na: sodium; Ca: calcium; Mg: magnesium; $\mathrm{PCO}_{2}$ : $\mathrm{CO}_{2}$ partial pressure; $\mathrm{HCO}_{3}$ : bicarbonate; F: female; $\mathrm{M}$ : male; aStudent's t-test for paired samples (between $t 2$ and $t 3$ average); ${ }^{b}$ means differing from reference values. 
in this disease, which clinically presents with physical signs of malnutrition in various systems, may, on the one hand, cause the less trained clinician to downplay the severity, and, on the other, endorse the patient's behavior, who may understand that their values are within laboratory references.

As mentioned, the most frequent laboratory alterations in this sample were venous blood gas analysis and ferritin. Data in the literature regarding blood gas changes in patients with anorexia are controversial. Some studies reporte normal values, ${ }^{24,25}$ while others report that changes in (venous) blood gases are frequent. ${ }^{11,12}$ Different results may be related to different methodologies, namely related to age, disease phase (decompensated versus "stable"), and use of arterial versus venous blood gas analysis. Kerem et al. ${ }^{11}$ reported that mild respiratory acidosis is common in venous blood gas analysis in adolescents with recent diagnosis of $\mathrm{AN}$ and hospitalized for clinical stabilization (78\% at admission and 35\% at hospital discharge). These data show that changes in venous blood gases are also frequent in adolescents in outpatient follow-up and at different stages of the disease.

Although there was no direct correlation between BMI $\mathrm{Z}$-score and venous blood gas parameters, at the consultation with the worst BMI $(\mathrm{t} 2)$, all patients had respiratory acidosis, which is in agreement with data reported by Kerem et al. ${ }^{11}$ There was a decrease in the number of patients with unbalanced acidosis from $\mathrm{t} 2$ to $\mathrm{t} 3$, associated with a significant decrease of mean $\mathrm{pCO}_{2}(57.2$ versus $53.6 \mathrm{mmHg}$; $=0.009)$ and mean $\mathrm{HCO}_{3}(30.0$ versus $28.8 \mathrm{mEq} / \mathrm{L} ; \mathrm{p}=0.023)$ between $\mathrm{t} 2$ and $\mathrm{t} 3$.

This data seems to place blood gas analysis as a useful tool for disease monitoring, since BMI recovery was associated with a tendency to normalize venous blood gas values. Several physiological mechanisms may explain the presence of respiratory acidosis in AN patients: changes in muscle strength of the muscles involved in breathing (particularly the diaphragm), ${ }^{25,26}$ abnormalities in respiratory control (increased vagal tone $)^{24,26}$ and possible changes in pulmonary function (emphysema-like changes). ${ }^{27}$

In this sample, ferritin was altered: elevated in $\mathrm{t} 1$ and t2 and with tendency to normalization in t3. Compared to changes in venous blood gas analysis, ferritin elevation was less frequent and ferritin decrease was not statistically significant $(\mathrm{p}=0.196)$. Although these results are not consensual in the literature, ${ }^{17}$ several authors have reported increased ferritin values in AN patients, with a tendency to normalization associated with weight recovery. ${ }^{15,16,28-30}$ Ferritin is frequently used to evaluate Iron stores, but may be elevated in situations such as liver damage, neoplasia, infection, and inflammation. Thus, it is difficult to interpret its elevation in AN patients, and, currently, its pathophysiological mechanism is not clear.

In a study by Papillard-Marechal et al., ${ }^{28}$ ferritin and hepcidin concentration was high in AN patients, with no evidence of iron overload or hemolysis, and with inflammatory parameters and normal liver tests. The authors suggest that acute malnutrition may be a source of stress at the hepatocyte level, leading to an increase in hepcidin and, consequently, ferritin. Nova et al. ${ }^{15}$ argue that ferritin increases in response to a process of adaptation to food restriction, with normalization once weight is recovered.

Our study had some limitations because it was a retrospective analysis, with a small convenience sample and few male adolescents. Considering the study period, in three cases the clinical and laboratory evaluation was made only at the first consultation, since the subsequent consultations were later than the time period considered. These were the cases of two female adolescents and one male, which does not change the overall representativeness of the sample in terms of gender, although in the context of a small sample, it accounts for $12.5 \%$ of the total.

In addition, the laboratory evaluation was not completely homogeneous at the different moments and there was no control group. Other relevant clinical information, such as laxative

Table 4 Venous blood gas analysis.

\begin{tabular}{l|c|c|c|c}
\hline Venous blood gas analysis & $t 1(n=22)$ & $t 2(n=20)$ & $t 3(n=17)$ & $p$-value \\
\hline $\mathrm{pH}$ & $7.34 \pm 0.03^{\mathrm{a}}$ & $7.33 \pm 0.02^{\mathrm{a}}$ & $7.34 \pm 0.02^{\mathrm{a}}$ & $0.213^{\mathrm{b}}$ \\
\hline $\mathrm{PCO}_{2}(\mathrm{mmHg})$ & $53.8 \pm 6.5^{\mathrm{a}}$ & $56.6 \pm 5.1^{\mathrm{a}}$ & $53.5 \pm 5.2^{\mathrm{a}}$ & $0.009^{\mathrm{b}}$ \\
\hline $\mathrm{HCO}_{3}(\mathrm{mEq} / \mathrm{L})$ & $28.9 \pm 2.0$ & $29.9 \pm 1.6$ & $28.7 \pm 39.7$ & $0.230^{\mathrm{b}}$ \\
\hline Respiratory acidosis & $20(91 \%)$ & $20(100 \%)$ & $16(95 \%)$ & $\mathrm{NA}$ \\
\hline $\begin{array}{l}\mathrm{Compensated} \mathrm{respiratory} \mathrm{acidosis} \\
\left(\mathrm{pH} 7.35-7.45 \text { e } \mathrm{pCO}_{2}>45\right)\end{array}$ & $11(50 \%)$ & $7(35 \%)$ & $7(41 \%)$ & $\mathrm{NA}$ \\
\hline $\begin{array}{l}\text { Non-compensated respiratory acidosis } \\
\left(\mathrm{pH}<7.35 \text { e } \mathrm{PCO}_{2}>45\right)\end{array}$ & $9(41 \%)$ & $13(65 \%)$ & $9(53 \%)$ & $0.453^{\mathrm{c}}$ \\
\hline
\end{tabular}

$\mathrm{pCO}_{2}$ : $\mathrm{CO}_{2}$ partial pressure; $\mathrm{HCO}_{3}$ : bicarbonate; $\mathrm{NA}$ : not applicable; altered means related to reference values; 'btudent's t-test for paired samples (between $t 2$ and $t 3$ mean); ${ }^{C}$ McNemar test (between $t 2$ and $t 3$ ). 
intake, quantification of vomiting, physical exercise, and medication or drug/alcohol/tobacco intake were not considered. It would also be important to assess respiratory rate, as it could help to understand the mechanism associated with respiratory acidosis in these patients. A prospective study with greater sampling power could surpass such limitations. It would also be interesting to include other eating disorders.

In conclusion, this study showed that changes in laboratory tests commonly requested are uncommon in adolescents with AN followed up at the outpatient clinics. On the other hand, venous blood gas analysis (in almost all patients) and ferritin (in a smaller percentage and with probable interpretation limitations) were frequently altered. Thus, it is considered that both tests should be included in the laboratory evaluation of patients with AN. Specifically, the presence of respiratory acidosis in venous blood gas analysis in these patients was associated with greater clinical severity and may be an early marker of decompensation. In the future and by further studies, venous blood gas analysis may be clinically useful in the risk stratification of outpatients with AN followed up for monitoring/recovery.

\section{Funding}

This study did not receive funding.

\section{Conflict of interests}

The authors declare no conflict of interests.

\section{REFERENCES}

1. Rosen DS, American Academy of Pediatrics. Identification and management of eating disorders in children and adolescents. Pediatrics. 2010;126:1240-53. https://doi. org/10.1542/peds.2010-2821

2. Campbell K, Peebles R. Eating disorders in children and adolescents: state of the art review. Pediatrics. 2014;134:58292. https://doi.org/10.1542/peds.2014-0194

3. Smink FR, Hoeken D, Oldehinkel AJ, Hoek HW. Prevalence and severity of DSM-5 eating disorders in a community cohort of adolescents. Int J Eat Disord. 2014;47:610-9. https://doi.org/10.1002/eat.22316

4. Moinho R, Dias I, Luz A, Moleiro P. Eating disorders in boys: what are the differences? Acta Pediatr Port. 2014;45:124-9.

5. Bacalhau S, Moleiro P. Eating disorders in adolescents - what to look for? Acta Med Port. 2010;23:777-84.

6. American Psychiatric Association. Diagnostic and statistical manual of mental disorders. 5th ed. Washington (DC): American Psychiatric Association; 2013.

7. Moinho R, Dias I, Luz A, Moleiro P. Feeding and eating disorders in a paediatric outpatient clinic: the impact of DMS-5. Acta Pediatr Port. 2016;47:3-10.

8. Winston AP. The clinical biochemistry of anorexia nervosa. Ann Clin Biochem. 2012;49:132-43. https://doi.org/10.1258/ acb.2011.011185

9. Vale B, Brito S, Paulos L, Moleiro P. Menstruation disorders in adolescents with eating disorders-target body mass index percentiles for their resolution. Einstein (Sao Paulo). 2014;12:17580. http://dx.doi.org/10.1590/S1679-45082014AO2942

10. Miller KK, Grinspoon SK, Ciampa J, Hier J, Herzog D, Klibanski A. Medical findings in outpatients with anorexia nervosa. Arch Intern Med.2005;165:561-6. https://doi.org/10.1001/archinte.165.5.561

11. Kerem NC, Riskin A, Averin E, Srugo I, Kugelman A, Tov N. Respiratory acidosis in adolescents with anorexia nervosa hospitalized form medical stabilization: a retrospective study. Int J Eat Disord. 2012;45:125-30.
12. Kerem NC, Averin E, Riskin A, Toy N, Srugo I, Kugelman A. Respiratory functions in adolescents hospitalized for anorexia nervosa: a prospective study. Int J Eat Disord. 2012;45:415-22. https://doi.org/10.1002/eat.20960

13. Casanova T, Santos P, Figueiredo C, Silveira A. Anorexia nervosa: proposta de linhas orientadoras. Acta Pediatr Port. 2009;40:133-5.

14. Nova E, Lopez-Vidriero I, Varela P, Casas J, Marcos A. Evolution of serum biochemical indicators in anorexia nervosa patients: a 1-year follow-up study. J Hum Nutr Diet. 2008;21:23-30. https://doi.org/10.1111/j.1365-277X.2007.00833.x

15. Nova E, Lopez-Vidriero I, Varela P, Toro O, Casas JJ, Marcos AA. Indicators of nutritional status in restricting-type anorexia nervosa patients: a 1-year follow-up study. Clin Nutr. 2004;23:1353-9. https://doi.org/10.1016/j.clnu.2004.05.004

16. Kennedy A, Kohn M, Lammi A, Clarke S. Iron status and haematological changes in adolescent female inpatients with anorexia nervosa. J Paediatr Child Health. 2004;40:430-2. https://doi.org/10.1111/j.1440-1754.2004.00432.x

17. Barron LJ, Barron RF, Johnson JC, Wagner I, Ward CJ, Ward SR, et al. A retrospective analysis of biochemical and haematological parameters in patients with eating disorders. J Eat Disord. 2017;5:32. https://doi.org/10.1186/ s40337-017-0158-y

18. Yildizdas D, Yapicioğlu H, Yilmaz H, Sertdemir Y. Correlation of simultaneously obtained capillary venous, and arterial blood gases of patients in a paediatric intensive care unit. Arch Dis Child. 2004;89:176-80. https://doi.org/10.1136/ adc.2002.016261

19. Malatesha G, Singh NK, Bharija A, Rehani B, Goel A. Comparison of arterial and venous $\mathrm{pH}$, bicarbonate, $\mathrm{PCO} 2$ and $\mathrm{PO} 2$ in initial emergency department assessment. Emerg Med J. 2007;24:569-71. https://doi.org/10.1136/emj.2007.046979 
20. Kliegman RM, Stanton B, Geme JS, Schor NF, Behrman RE, editors. Nelson Textbook of Pediatrics. 19th ed. Philadelphia: WB Saunders Company; 2011.

21. Portugal. Serviço Nacional de Saúde (SNS). Documentos e Publicações. Programa Nacional de Saúde Infantil e Juvenil [homepage on the Internet]. Portugal; 2005 [cited 2017 Aug 14]. Available from:https://www.dgs.pt/documentos-e-publicacoes/ programa-tipo-de-atuacao-em-saude-infantil-e-juvenil.aspx.

22. Bryman A, Cramer D. Quantitative data analysis for social scientists. London: Routledge; 1995.

23. Rigaud D, Tallonneau I, Vergès B. Hypercholesterolaemia in anorexia nervosa: frequency and changes during refeeding. Diabetes Metab. 2009;35:57-63. https://doi.org/10.1016/j.diabet.2008.08.004

24. Pieters T, Boland B, Beguin C, Veriter C, Stanescu D, Frans A, et al. Lung function study and diffusion capacity in anorexia nervosa. J Intern Med. 2000;248:137-42.

25. Gonzalez-Moro JM, Miguel-Diez J, Paz-González L, Buendía-García MJ, Santacruz-Siminiani A, Lucas-Ramos P. Abnormalities of the respiratory function and control of ventilation in patients with anorexia nervosa. Respiration. 2003;70:490-5. https://doi.org/10.1159/000074205
26. Gardenghi Gardenghi G, Boni E, Todisco P, Manara F, Borghesi A, Tantucci C. Respiratory function in patients with stable anorexia nervosa. Chest. 2009;136:1356-63. https://doi. org/10.1378/chest.08-3020

27. Coxson HO, Chan IH, Mayo JR, Hlynsky J, Nakano Y, Birmingham CL. Early emphysema in patients with anorexia nervosa. Am J Respir Crit Care Med. 2004;170:748-52. https://doi.org/10.1164/rccm.200405-6510C

28. Papillard-Marechal S, Sznadjer M, Hurtado-Nedelec M, Alibay $Y$, Martin-Schmitt C, Dehoux $M$, et al. Iron metabolismo in patients with anorexia nervosa: elevated serum hepcidin concentrations in the absence of inflammation. Am J Clin Nutr. 2012;95:548-54. https://doi.org/10.3945/ajcn.111.025817

29. Wanby P, Berglund J, Brudin L, Hedberg D, Carlsson M. Increased ferritin levels in patients with anorexia nervosa: impact of weight gain. Eat Weight Disord. 2016;21:411-7. https://doi.org/10.1007/s40519-015-0246-4

30. Tran J, Story C, Moore D, Metz M. Unexpected increased ferritin concentration in patients with anorexia nervosa. Ann Clin Biochem. 2013;50:504-6. https://doi. org/10.1177/0004563213490289 